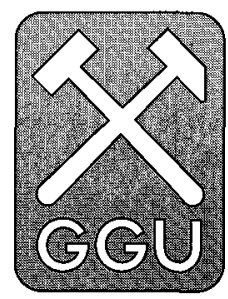

\title{
Search for meteoritic components in the 3800 million years old Isua supracrustal belt, West Greenland
}

\author{
Peter W. U. Appel and Marc Chaussidon
}

The Isua supracrustal rocks of West Greenland have been in international focus ever since their earliest Archaean age was demonstrated in the early 1970s. For years they were highlighted as the Earth's oldest rocks. Although the 'oldest rocks' tag has now passed elsewhere, the wellpreserved Isua supracrustal sequence still attracts research projects directed towards understanding the Earth's history.

This note refers to one such project, carried out by the Geological Survey of Greenland in collaboration with Centre de Recherches Pétrographiques et Géochimiques, Nancy, France, concerning the recognition of cosmic material in the Isua rocks. Field work in 1993 concentrated on detailed sampling of a chert sequence.

\section{The concept}

All models of Earth formation and evolution invoke the accretion to the forming Earth of meteoritic objects of various sizes (Wetherill, 1990), but there is no consensus on the timing of this process. Some models require a rapid accretion, i.e. within a few hundred million years from Earth formation, while others assume a more continuous accretion process during the first 1000 million years of Earth history. Any direct proof of collision between extraterrestrial material and the Earth during the Early Archaean is presently lacking (Shoemaker, 1983). The discovery of meteorites or fragments of meteorites in Early Archaean rocks would therefore be of great importance in constraining models of the accretion process.

Material of cosmic origin is frequently found on Earth, either in the form of meteorites or as meteoritic dust. In modern deep-sea sediments tiny spheres originating from meteorites are found (Blanchard et al., 1978), and in some of these spheres relict mineral grains may be present, i.e. grains which were not melted before ablation from the parent meteorite. Among the mineral grains identified is chromite (Blanchard et al., 1978).

The amount of cosmic material being deposited on the Earth's surface today is very small, compared with the early period of the Earth's history. The last major meteoritic bombardment which hit the Earth-Moon system took place 3900 to 3800 million years ago (Papanastassiou \&
Wasserburg, 1971, 1972). This is very close or perhaps coeval with the formation of the Isua supracrustal belt (Fig. 1) about 3800 million years ago (Moorbath et al., 1973).

The Isua supracrustal belt comprises mainly mafic volcanic rocks such as pillow lavas, intercalated with chemical precipitates such as chert, a banded iron-formation and carbonates; also present are felsic pyroclastics and ultramafic metasediments. The Isua sediments were probably deposited on an ocean floor under conditions resembling modern deep-sea sedimentation. Subsequent to deposition the Isua rocks were deformed and metamorphosed under amphibolite facies conditions.

\section{Search for meteoritic material}

The first traces in the Isua supracrustal rocks of supposed meteoritic material were found in 1979; these are tiny chromite grains of the order of 15 to $40 \mu$ in size in the Isua iron-formation (Fig. 2). The chromite grains occur as inclusions in magnetite grains in different facies of

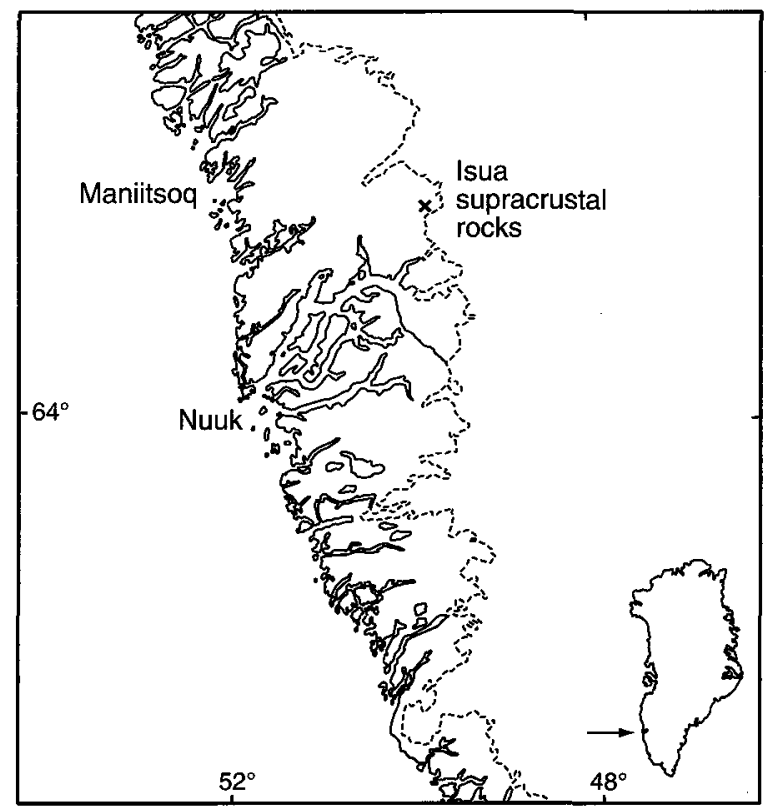

Fig. 1. Map showing location of the Isua supracrustal belt. 


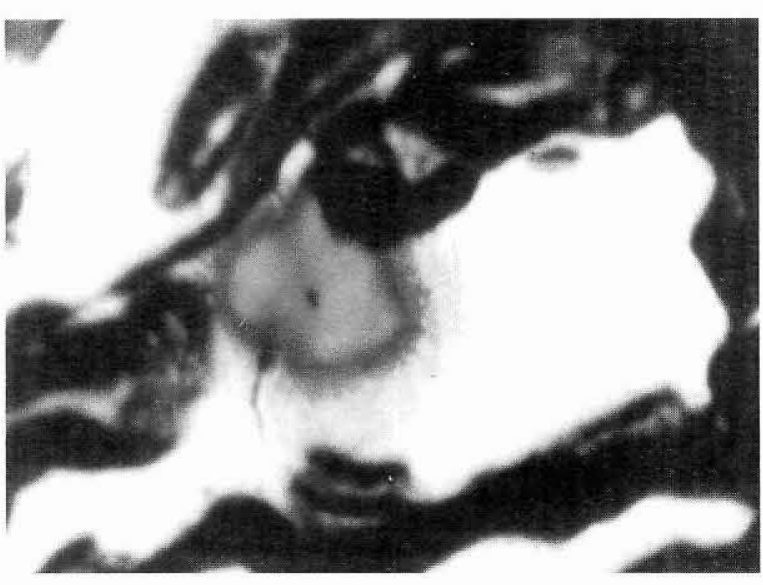

Fig. 2. Chromite grain about $20 \mu$ across, enclosed in magnetite in the Isua iron-formation.

iron-formation. They have a peculiar chemical composition with $\mathrm{ZnO}$ contents up to $1.66 \%$, which is comparable to chromite grains found in iron-meteorites (Bunch et al., 1970). Although the chromite grains have reacted chemically with the surrounding magnetite during metamorphism, the central parts of the chromite grains are believed to represent the original composition. Based on their chemical composition and the low energy environment in which the chromite grains were deposited Appel (1979) argued that the chromite grains were of extra-terrestrial origin.

Detailed sampling was later carried out across beds of different facies of banded iron-formation. The samples were analysed for major and trace elements and reveal several significant chromium anomalies. The most chromium-rich samples were subsequently analysed for iridium by neutron activation, but all results were below detection limit ( $5 \mathrm{ppb}$ ). The presence of iridium anomalies in sediments has been suggested as evidence for major meteorite impact events. A programme involving detailed microscopic investigation of polished thin sections from the Isua banded iron-formation is planned.

Detailed sampling of a chert bed was carried out in 1993, and the samples are at present being analysed for iridium.

\section{Isotope investigations}

The suggestion that the chromite grains in the Isua banded iron-formation are of extra-terrestrial origin cannot be resolved until unequivocal evidence is found. It is therefore intended to undertake a survey of $\mathrm{Mg}$ isotope composition of chromite grains by ion probe. ${ }^{26} \mathrm{Mg}$ is produced by the decay of ${ }^{26} \mathrm{Al}$, a short lived nuclide with $7.4 \times 10^{5}$ years half life. $\mathrm{Mg}$ isotope anomalies are present in high temperature minerals which condensed from the solar nebula a short time (less than about 1 million years) after the formation of ${ }^{26} \mathrm{Al}$ during the pre-solar nucleosynthesis. If no secondary process such as metamorphism or re-melting has occurred, anomalies will be retained in the minerals to the present day, and can be detected by mass spectrometry or in situ ion probe analysis (e.g. Lee et al., 1976; Zinner et al., 1991). The Isua chromite grains represent a favourable case in a search for excess ${ }^{26} \mathrm{Mg}$ because (1) they are Al-rich and Mg-poor (Al/Mg ratio of about 100, Appel, 1979) and (2) because chromite grains of similar composition are known in chondrites (Bunch et $a$ l., 1967).

If excess ${ }^{26} \mathrm{Mg}$ is found in the Isua chromite grains, their cosmic origin will be definitely proved. In that case, iron probe analysis for other isotope anomalies (e.g. $\mathrm{Si}, \mathrm{Ti}, \mathrm{Fe}$, $\mathrm{Cr}$ ) and trace element variation may help to place constraints on the type of extra-terrestrial material which has impacted the lsua rocks.

\section{References}

Appel, P. W. U. 1979: Cosmic grains in an iron-formation from the Early Precambrian Isua supracrustal belt. West Greenland. J. Geol. 87, 573-578.

Blanchard, M. B., Brownlee. D. E., Bunch, T. E., Hodge, P. W. \& Kyte, F. T. 1978: Meteor ablation spheres from deep-sea sediments. NASA Technical Memorandum 78510, $42 \mathrm{pp}$.

Bunch, T. E., Keil, K. \& Snetsinger, K. G. 1967: Chromite composition in relation to chemistry and texture of ordinary chondrites. Geochim. Cosmochim. Acta 31, 1569-1582.

Bunch, T. E., Keil, K. \& Olsen, E. 1970: Mineralogy and petrology of silicate inclusions in iron meteorites. Contrib. Mineral Petrol. 25, 297-340.

Lee, T., Papanastassiou, D. A. \& Wasserburg, G. J. 1976: Demonstration of ${ }^{26} \mathrm{Mg}$ excess in Allende and evidence for ${ }^{26} \mathrm{Al}$. Geophys. Res. Lett. 3, 109-112.

Moorbath, S., O'Nions, R. K. \& Pankhurst, R. J. 1973: Early Archaean age for the Isua iron formation, West Greenland. $\mathrm{Na}$ ture, $\mathbf{2 4 5}, 138$ only.

Papanastassiou, D. A. \& Wasserburg, G. J. 1971: Rb-Sr ages of igneous rocks from the Apollo 14 mission and the age of the FRA Mauro formation. Earth Planet. Sci. Lett. 12, 36-48.

Papanastassiou, D. A. \& Wasserburg, G. J. 1972: The Rb-Sr age of a crystalline rock from Apollo 16. Earth Planet. Sci. Lett. 16. $289-298$.

Shoemaker E. M. 1983: Asteroid and comet bombardment of the Earth. Ann. Rev. Earth Planet. Sci. 11, 461-494.

Wetherill, G. W. 1990: Formation of the Earth. Ann. Rev. Earth Planet. Sci. 18, 205-256

Zinner, E., Amari, S., Anders, E. \& Lewis, R. 1991: Large amounts of extinct ${ }^{26} \mathrm{Al}$ in interstellar grains from the Muchinson meteorite. Nature $349,51-54$.

P. W. U. A., Geological Survey of Greenland, Copenhagen M. S., Centre de Recherches Pétrographiques et Géochimiques, Nancy, France 